\title{
Decolorization of Novacron Blue and Novacron Super Black Azo Dyes by Bacillusspp Isolated from Textile Effluents in Bangladesh
}

\author{
K. R. Mahbub ${ }^{1}$, B. Morium ${ }^{2}$, M. M. Ahmed ${ }^{1 *}$, M. A. Akond ${ }^{2}$, S. Andrews ${ }^{3}$ \\ ${ }^{1}$ Industrial Microbiology Laboratory, Institute of Food Science and Technology, BCSIR, \\ Dhanmondi, Dhaka 1205, Bangladesh \\ ${ }^{2}$ Department of Botany, Jahangirnagar University, Savar, Dhaka, Bangladesh \\ ${ }^{3}$ University of South Australia, Mawson Lakes, Adelaide SA 5095, Australia.
}

Received 23 April 2014, accepted in final revised form 9 March 2015

\begin{abstract}
Effluents containing azo dyes from textile and dyeing industries cause serious pollution to aquatic environments. In this study, azo dye decolourization potential of five bacterial isolates was examined in different physicochemical conditions such as $\mathrm{pH}$, temperature and glucose concentrations. Based on biochemical characteristics the isolates were identified as Bacillus badius (isolate A3 and A4) and Bacillus sphaericus (isolate A5, B8, C5). These bacteria showed decolourization of two experimental azo dyes, Novacron Blue and Novacron Super Black at different temperatures, $\mathrm{pH}$ and glucose concentrations up to $92 \%$ after $72 \mathrm{~h}$ of incubation. Decolourization increased with time and temperature. Neutral to alkaline $\mathrm{pH}$ with increased concentration of glucose facilitated dye removal. The maximum decolourization $(92 \%)$ of experimental dyes was observed at $35^{\circ} \mathrm{C}, \mathrm{pH} 7-8$ with $2 \%$ glucose. Bacillus badius demonstrated better decolourization.
\end{abstract}

Keywords: Textile effluent; Azo dye; Decolorization; Bacillus.

(c) 2015 JSR Publications. ISSN: 2070-0237 (Print); 2070-0245 (Online). All rights reserved.

doi: http://dx.doi.org/10.3329/jsr.v7i1-2.18682 J. Sci. Res. 7 (1-2), 45-53 (2015)

\section{Introduction}

Highly colorful textile effluents when discharged into open water create environmental pollution. The discharge of untreated dye-containing effluents into the aquatic environment is undesirable, not only because of their color, but also because many of residual dyes and their breakdown products such as benzidine, naphthalene and other aromatic compounds are toxic, carcinogenic or mutagenic to life forms [1-3]. If not treated, these dyes can remain in the environment for a long period of time. For instance, the half-life of hydrolyzed Reactive Blue 19 is about 46 years at $\mathrm{pH} 7.0$ and $25^{\circ} \mathrm{C}$ [4]. Due

Corresponding author: monzur_29@yahoo.com 
to their synthetic nature and aromatic structure, these azo dyes are classified as nonbiodegradable, having carcinogenic action or causing allergies, dermatitis, skin irritation or different cellular changes with either acute or chronic toxicity. The health risk is caused by adsorption of azo dyes and their breakdown product (toxic amines) through the gastrointestinal tract, skin, lungs, and by the formation of haemoglobin adducts and disturbance of blood formation. LD50 values reported for aromatic azo dyes range between 100 to $2000 \mathrm{mg} / \mathrm{kg}$ body weight [5]. Azo dyes can cause the genesis of malignant tumors due to DNA damage. Carcinogenic potential is attributed to electron-donating substituents in ortho and para position. The toxicity is diminished with the protonation of aminic groups [6]. Bioaccumulation of azo dyes in food chain and hypopigmentation by inhibiting tyrosinase enzyme activity has been demonstrated [7]. The traditional physicochemical processes of azo dye remediation are costly, less efficient and cause sludge problems. A number of bacteria capable of aerobic decolourization of azo dyes were reported in different literature which included Bacillus thuringiensis, Bacillus subtilis, Bacillus megaterium, Proteus vulgaris, Pseudomonas aeruginosa, Staphylococcus aureus, Escherichia coli [8-18], but these studies are limiting. The present study was aimed at studying the potential of some bacterial isolates in azo dye degradation and to optimize various physicochemical parameters such as $\mathrm{pH}$, temperature and glucose sources for efficient azo dye removal under laboratory conditions.

\section{Experimental}

Experimental organisms were collected from the culture collection of the Industrial Microbiology Laboratory at IFST, BCSIR, Dhaka, Bangladesh. These bacteria were previously isolated from a textile effluent contaminated area situated in Gazipur, Dhaka, Bangladesh and stored at $-80{ }^{\circ} \mathrm{C}$ by liquid freezing and coded as A3, A4, A5, B8 and C5 [15]. The isolates were reactivated by thawing at $4{ }^{\circ} \mathrm{C}$ and growing in nutrient broth and working stocks were prepared and maintained at $4^{\circ} \mathrm{C}$.

Novacrone Blue and Novacrone Super Black were used throughout the study. These dyes are reactive azo dyes, water soluble and are frequently used in most of the textile industries in Bangladesh. Although these dyes have different reactive systems, the dyes are of the same chemical class and function by forming reactive bonds with the substrates.

Decolourization activities of the isolates were studied on a chemically defined medium which was named M1 medium. The composition is as follows: Glucose 0.1-2\%, Yeast extract $0.034 \%, \mathrm{NH}_{4} \mathrm{Cl} 0.084 \%, \mathrm{KH}_{2} \mathrm{PO}_{4} 0.0134 \%, \mathrm{~K}_{2} \mathrm{HPO}_{4} 0.0234 \%, \mathrm{MgCl}_{2} .6 \mathrm{H}_{2} \mathrm{O}$ $0.0084 \%$, Nutrient broth $0.01 \%$. These ingredients were dissolved in distilled water, sterilized and supplemented with filter sterilized dye solutions.

Bacterial cultures were grown on nutrient agar to observe colony morphologies. Cell morphologies were characterized by Gram and spore staining. Biochemical tests performed included motility, indole, methyl red, Voges Proskauer, citrate utilization, catalase, oxidase, starch and casein hydrolysis, lysine iron agar, triple sugar iron agar, nitrate reduction, gelatin liquefaction, proteolysis, urease and carbohydrate fermentation 
tests as well as growth response at different temperatures, $\mathrm{pH}$ and salt concentrations [15]. Isolates were characterized by growing on polymixin pyruvate egg yolk mannitol bromothymol blue agar (PEMBA) (HiMedia, India) which is recommended for Bacillus selection. The isolates were then identified by comparing the test results with the descriptions in Bergey's Manual of Determinative Bacteriology [16].

To study the effect of different parameters on dye decolorization, M1 medium with different glucose concentrations and different $\mathrm{pH}$ values were prepared and dispensed into the test tubes (10 mL per test tube) and autoclaved. After autoclaving, the experimental dyes were individually mixed with filter sterilization to achieve $0.1 \mathrm{mg} / \mathrm{L}$ final concentration in M1 medium. The broths were inoculated with the individual test organisms and incubated in static condition.

During incubation decolorization of the azo dyes was determined at their respective maximum wavelength in the culture supernatant using a T60 UV VIS spectrophotometer (PG Instruments) [15]. Culture supernatants were prepared after centrifugation of broth culture at $10000 \mathrm{rpm}$ for $8 \mathrm{~min}$ and the absorbance was recorded at $595.5 \mathrm{~nm}$. This absorbance was compared with a standard curve prepared using concentrations of 0.0001 , $0.001,0.01,0.1 \mathrm{mg} / \mathrm{L}$ of the dyes. Then the efficiency of color removal was expressed as the percentage ratio of the decolorized dye concentration to that of initial one based on the following equation:

$\%$ Decolorization $=\frac{\text { Initial dye concentration }- \text { Residual dye concentration }}{\text { Initial dye concentration }} \times 100$

\section{Results and Discussions}

The bacterial isolates were identified on the basis of their morphological, physiological and biochemical characteristics as described [16]. The test results are presented in Table 1. All of the isolates were gram positive short rods, arranged singly, in pair and sometimes in chains (Fig. 1a). Centrally located cylindrical endospores were found in isolate A3 (Fig. 1b) and A4 whereas endospores in the other isolates were located terminally.

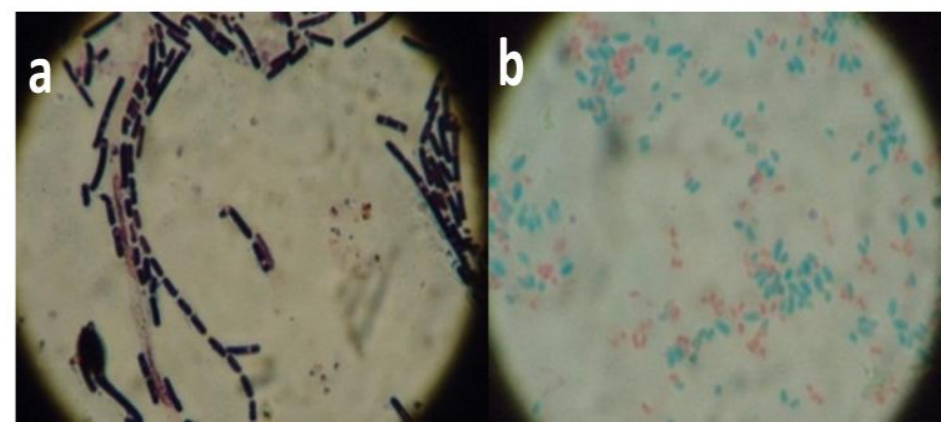

Fig. 1. (a) Vegetative cells of the isolate B8 (40X); (b) endospore of the isolate A3 (100X). 
After detail characterization, the test results were compared with the description in Bergey's Manual of Determinative bacteriology [16] and the isolates were identified as Bacillus badius (Isolates A3, A4) and Bacillus sphaericus (Isolates A5, B8, C5).

Table 1. Biochemical behavior of the selected bacterial isolates.

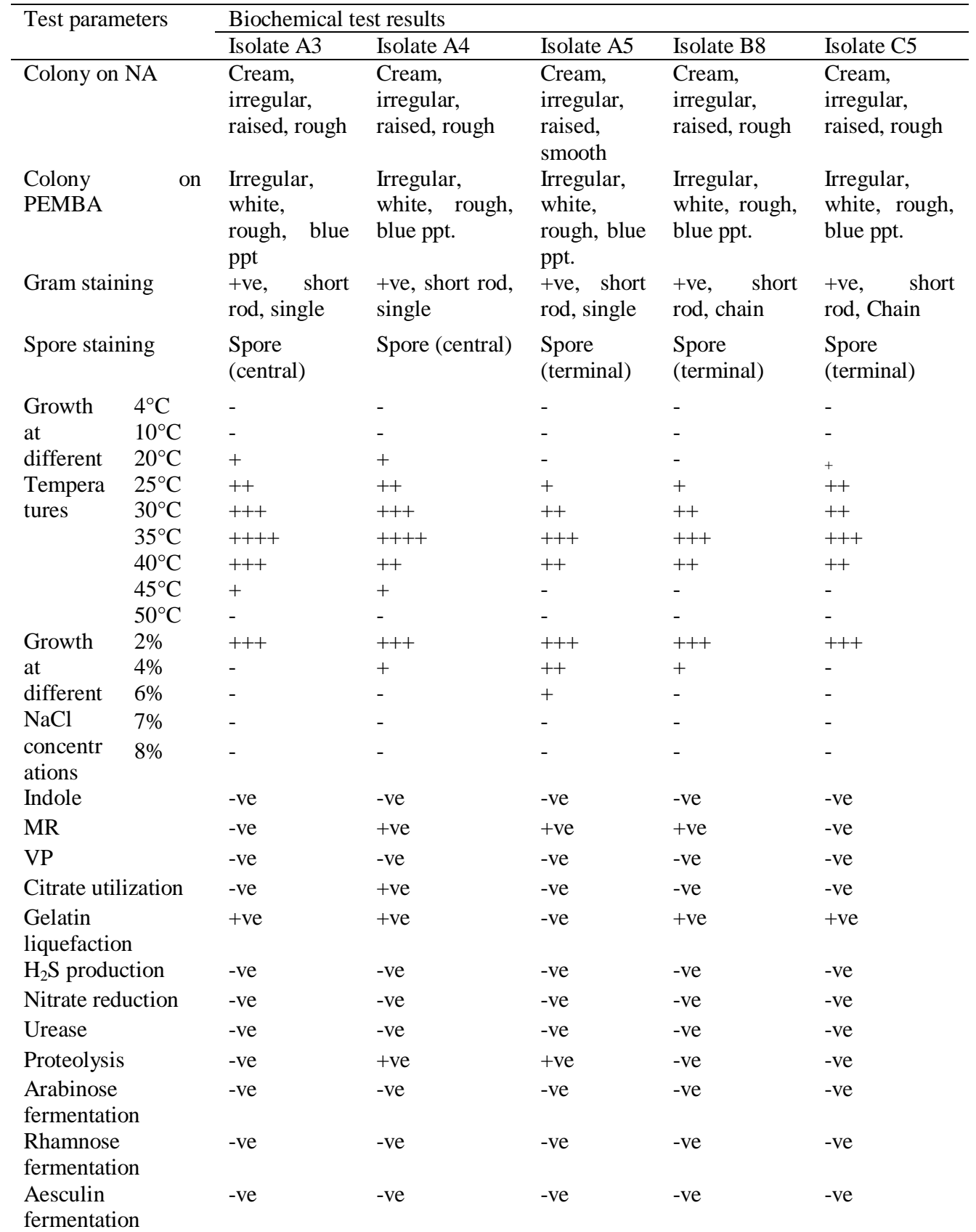


fermentation

Glucose

fermentation

Xylose

fermentation

Sucrose

fermentation

Mannitol

fermentation

Arginine

Oxidase

Catalase

TSI

LIA

Isolates identified*

$\begin{array}{ll}\text { Isolate A3 } & \text { Isolate A4 } \\ \text {-ve } & \text {-ve }\end{array}$

-ve

-ve $\quad-$ ve

-ve $\quad-$ ve

-ve $\quad-$ ve

$+v e$

-ve

$+\mathrm{ve}$

ys/yb

$\mathrm{ps} / \mathrm{yb}$

Bacillus

badius

Isolate A5
-ve
-ve
-ve

Isolate B8

-ve

-ve $\quad$-ve

-ve $\quad-v e$

-ve $\quad-$ ve $\quad-$ ve

-ve $\quad-$ ve $\quad-$ ve

$+\mathrm{ve}+\mathrm{ve}+\mathrm{ve}$

+ve $\quad-v e \quad-v e$

$+\mathrm{ve}+\mathrm{ve}+\mathrm{ve}$

$\mathrm{ys} / \mathrm{yb} \quad \mathrm{rs} / \mathrm{yb} \quad \mathrm{ys} / \mathrm{yb}$

$\mathrm{ys} / \mathrm{yb} \quad \mathrm{ps} / \mathrm{pb} \quad \mathrm{ys} / \mathrm{yb}$

Bacillus Bacillus Bacillus

sphaericus sphaericus sphaericus

Note: "+ve" indicates positive reaction, "-ve" indicates negative reaction, 'rs'= red slant, ' $y b$ '= yellow butt, 'ys'=yellow slant, 'ps'= purple slant, 'pb'=purple butt. “+”" indicates growth $(+=$ Scanty, $++=$ Moderate, $+++=$ Good, ++++heavy); “-” indicates no growth. *[16]

The effect of glucose concentration on the rate and extent of decolorization were measured using all five bacterial isolates. The initial concentration of dye used was 0.1 $\mathrm{mg} / \mathrm{L}$ and $0.1,0.25,0.5,1.0$ and $2.0 \%$ glucose solutions were used. The percentages of decolorization of Novacrone Blue for each isolate using the five glucose concentrations are presented in Fig. 2. It is apparent that increasing the glucose concentration increases the extent of dye decolorized. It was also obvious that the five bacterial isolates had similar capacity to decolorize the dye. All five selected isolates were tested on Novacrone Super Black and again 2\% glucose provided the highest decolorization (Fig. 3). The effect of glucose on the removal of Novacrone Super Black was similar in isolate A3 and A4, both from same group (Bacillus badius). Therefore data for only A3 is shown in Fig. 3. The results of the three other isolates of Bacillus sphaericus were similar and therefore the results of B8 are presented depicted only in Fig. 3. The extent and the rates of decolorization of both Novacrone Blue and Novacrone Super Black are not very different, indicating that both dyes degraded similarly.

Each of the selected isolates was tested on both Novacrone Blue and Novacrone Super Black separately to study the effect of different temperatures on decolorization. The different temperatures used were $20^{\circ} \mathrm{C}, 30^{\circ} \mathrm{C}, 35^{\circ} \mathrm{C}$ and $40^{\circ} \mathrm{C}$. After $72 \mathrm{~h}$ of incubation all five isolates showed similar decolorization pattern for both dyes. Decolorization increased with temperature and the highest was observed at $35^{\circ} \mathrm{C}$. Decolorization was observed to decrease at $40^{\circ} \mathrm{C}$. Therefore the optimum temperature for decolorization of the experimented dyes was $35^{\circ} \mathrm{C}$. Since the decolorization patterns at different temperatures were similar, so only the activities of isolate A4 from Bacillus badius and isolate C5 from Bacillus sphaericus are presented in Fig. 4. 

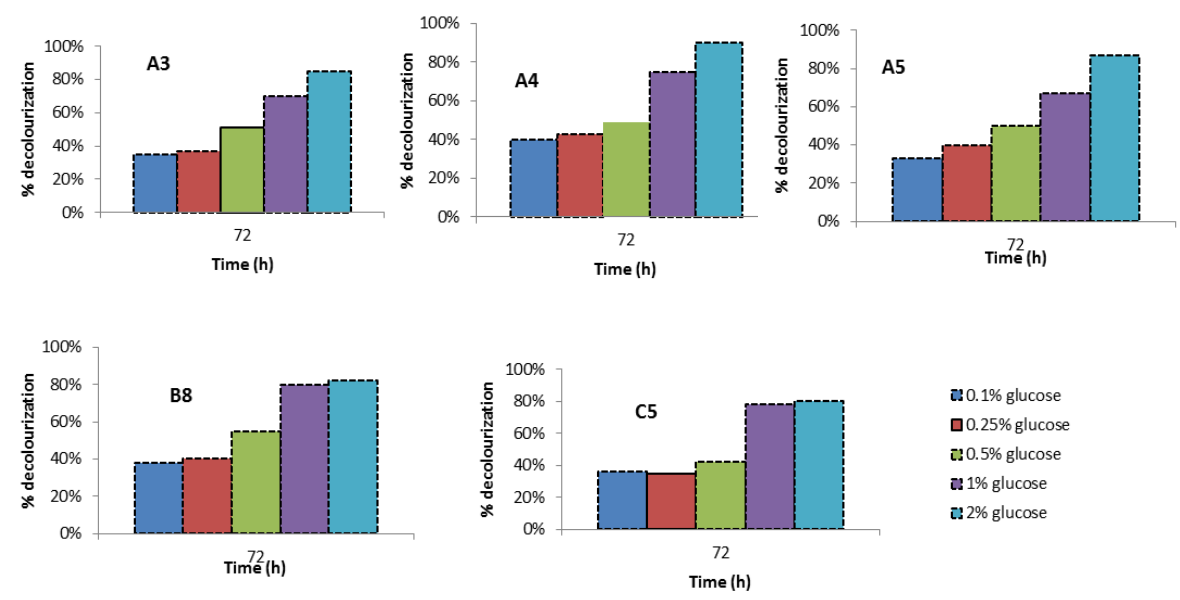

Fig. 2. Decolorization percentages of Novacron Blue by selected isolates at different glucose concentrations after $72 \mathrm{~h}$.
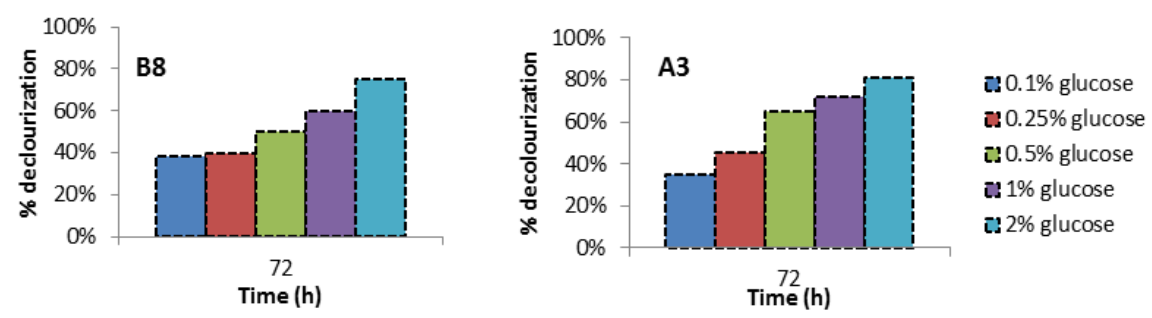

Fig. 3. Decolorization percentages of Novacron Super Black by B8 and A3 at different glucose concentrations after $72 \mathrm{~h}$.

The five isolates were experimented on both Novacrone Blue and Novacrone Super Black separately to study the effect of $\mathrm{pH}$ on decolorization. All isolates showed same decolorization pattern at different $\mathrm{pH}$. Both $B$ badius and $B$ sphaericus demonstrated that the optimum $\mathrm{pH}$ for decolorization is close to $\mathrm{pH} 7$ and rate of decolorization are reduced below $\mathrm{pH} 6$ and above $\mathrm{pH}$ 8.5. All isolates gave the same result; therefore results of only isolates A4 and A5 for both dyes are given in Fig. 5.

This study has demonstrated that Bacillus badius and Bacillus sphaericus can decolorize upto $90 \%$ of Novacrone blue and Novacrone super black at $35^{\circ} \mathrm{C}$ and neutral $\mathrm{pH}$ when $1-2 \%$ glucose is available. In the present study it was observed that neutral to alkaline $\mathrm{pH}$ favours decolorization and this is most effective at approximately $35^{\circ} \mathrm{C}$. In previous literatures, optimal $\mathrm{pH}$ for decolorization of most of the dyes was reported to be 6 to 10 [19]. Bacillussp was observed to perform good decolorization at $\mathrm{pH} 8.0,35^{\circ} \mathrm{C}$ and 
in static conditions [20]. Since azo dyes bind to fibres in alkaline conditions, the pH tolerance is an important factor for adapted bacteria [21]. Decolorization of azo dyes such as ramazol blue ceased at higher temperatures because of enzyme deactivation or viability loss [22]. Previous studies [23] suggested that $1 \%$ glucose is good for decolorization of azo dye ramazol black and the rate minimizes at $2 \%$ concentration which is contradictory to the present research where $2 \%$ glucose gave the best result.
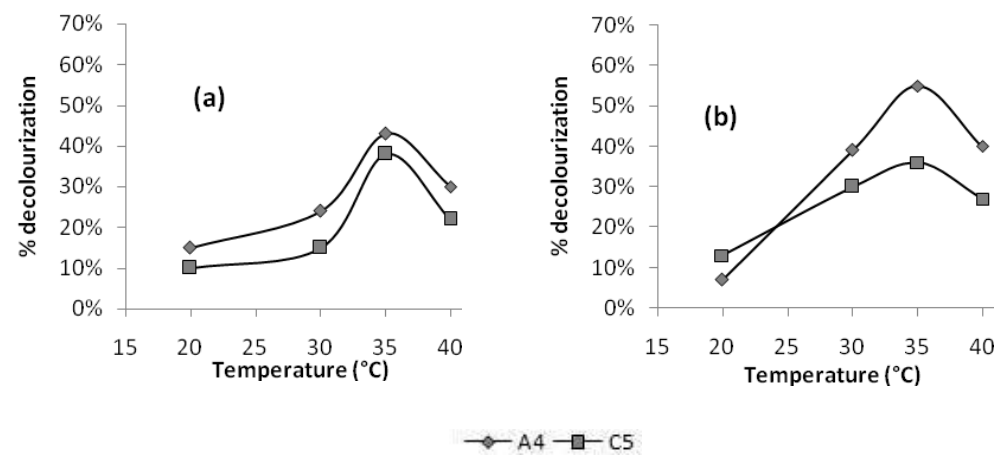

Fig. 4. Decolorization of Novacron Blue (a) and Novacrone Super Black (b) by isolates A4 ( $B$. badius) and C5 (B. sphaericus) at different temperatures after $72 \mathrm{~h}$.

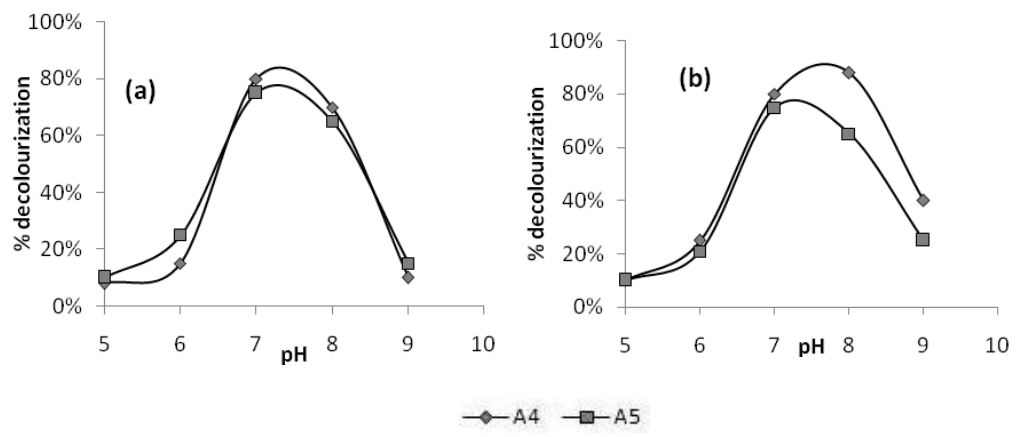

Fig. 5. Decolorization of Novacrone Blue (a) and Novacrone Super Black (b) by isolates A4 and A5 at different $\mathrm{pH}$ after $72 \mathrm{~h}$

Effluent adapted bacteria can be used as better candidates for decolorizing the effluent [24]. In a study, Bacillus subtilis SPR42 isolated from soil in the vicinity of textile industry was reportedly removed 60 to $80 \%$ of vaxent red and vaxent yellow azo dyes at $37^{\circ} \mathrm{C}$ [25]. Conversely present study shows 40 to $90 \%$ removal of two different azo dyes in almost same physical conditions. The Bacillus isolates reported in this study shows very good decolorization potential in laboratory condition. Since they are recovered from real contaminated area and show decolorization activity in a wide range of physicochemical parameters; can withstand higher $\mathrm{pH}$ and temperature similar to real effluent; these bacteria can be effectively used as biological tools for the treatment of textile effluents. 


\section{Conclusion}

Textile effluents in Bangladesh are a huge environment concern, setting up of ETP (Effluent Treatment Plant) is mandatory by present environment law. Along with chemical ETP, biological ETPs are getting established in the country day by day. In this context present study suggests that Bacillusspp isolated from local textile effluents can be used for further detailed investigation and applied research and might be exploited for decolorization of textile azo dyes present in textile industry effluents.

\section{References}

1. H. M. Pinheiro, E. Tourand, and O. Thomas, Dyes Pig. 61, 121 (2004). http://dx.doi.org/10.1016/j.dyepig.2003.10.009

2. D. Suteu, C. Zaharia, D. Bilba, A. Muresan, R. Muresan, and A. Popescu, Indus. Text. 60, 254 (2009).

3. C. Zaharia, D. Suteu, A. Muresan, R. Muresan, and A. Popescu, Environ. Eng. Man. J. 8, 1359 (2009).

4. O. J. Hao, H. Kim, and P. C. Chang, Crit. Rev. Environ. Sci. Technol. 30, 449 (2000). http://dx.doi.org/10.1080/10643380091184237

5. T. Reemtsma and M. Jekel, Organic Pollutants in the Water Cycle (Wiley-VCH Verlag GmbH \& Co. Weinheim, Germany 2006). http://dx.doi.org/10.1002/352760877X

6. I. M. Banat, P. Nigam, D. Singh, and R. Marchant, Biores. Technol. 58, 217 (1996). http://dx.doi.org/10.1016/S0960-8524(96)00113-7

7. S. K. Dubey, A. Pandey, A. K. Bajaj, and K. Mishra, J. Pharmacol.Toxicol. 2, 718 (2007). http://dx.doi.org/10.3923/ipt.2007.718.724

8. T. Robinson, G. McMullan, R. Marchant, and P. Nigam, Biores. Technol. 77, 247 (2001). http://dx.doi.org/10.1016/S0960-8524(00)00080-8

9. I. Kabdasli, M. Gurel, and O. Tunary, Environ. Technol. 21, 1147 (2000). http://dx.doi.org/10.1080/09593330.2000.9619001

10. S. H. Lin and L. M. Chen, Water Res. 31, 868 (1997). http://dx.doi.org/10.1016/S00431354(96)00318-1

11. S. Sharnaik and P. Kaneker, J. Appl. Bacteriol. 79, 459 (1995). http://dx.doi.org/10.1111/j.13652672.1995.tb03162.x

12. Y. Oztekin, Z. Yazicigil, N. Ata, and N. Karadayl, Clean-Soil Air Water 38, 478 (2010). http://dx.doi.org/10.1002/clen.200900292

13. Y. Anjaneyulu, C. N. Sreedhara, and R. D. S. Suman, Rev. Environ. Sci. Biotechnol. 4, 245 (2005). http://dx.doi.org/10.1007/s11157-005-1246-Z

14. K. R. Mahbub, J. Ferdouse, M. N. Anwar, Bang. J. Sci. Ind. Res. 46, 323 (2011).

15. K. R. Mahbub, A. Mohammad, M. M. Ahmed, and S. Begum, Asian J. Biotechnol. 4, 129 (2012). http://dx.doi.org/10.3923/ajbkr.2012.129.136

16. R. E. Buchanan and N. Gibbons, Bergey's Manual of Determinative Bacteriology (The William and Wilkons Co. Baltimore 1974).

17. M. A. Sukumar, A. Sivasamy, and G. Swaminathan, Appl. Biochem. Biotechnol. 136, 53 (2007). http://dx.doi.org/10.1007/BF02685938

18. L. S.Mihir, R. K. Mahbubar, and I. Farida, Bang. J. Microbiol. 23, 52 (2006).

19. K. C. Chen, W. T. Huang, J. Y.Wu, and J. Y. Houng, J. Ind. Microbiol. Biotechnol. 23, 686 (1999). http://dx.doi.org/10.1038/sj.jim.2900689

20. A. Prasad and K. B. Rao, Environ. Biotechnol. 2, 55 (2011).

21. Z. Aksu, Process Biochem. 23, 686 (2003). http://dx.doi.org/10.1016/S0032-9592(03)00034-7 
22. D. Cetin and G. Donmez, Enzyme Microbiol. Technol. 38, 926, (2006). http://dx.doi.org/10.1016/j.enzmictec.2005.08.020

23. K. Kumar, M. G. Dastidar, and T. R. Sreekrishnan, World Acd. Sci. Eng. Technol. 58, 962 (2009).

24. R. Leena and S. D. Raj, Afr. J. Biotechnol. 7, 3309 (2008).

25. S. S. Baljeet and R. Poonam, Int. J. Adv. Biotechnol. Res. 2, 148 (2011). 